Tersedia online di: http://ejournal-balitbang.kkp.go.id/index.php/JP
e-mail:jurnalpari@gmail.com
JURNAL PARI
Volume 3 Nomor 1 Juli 2017
p-ISSN: 2502-0730
e-ISSN : 2549-0133

\title{
PEMANFAATAN MEDIA SOSIAL DI PERPUSTAKAAN
}

\author{
Utilization of Social media in library
}

\section{ARIEF GUNAWAN}

Pusat Riset Perikanan

Diterima tanggal : 21 Maret 2017 diterima setelah perbaikan : 23 Mei 2017 disetujui terbit : 28 Juni 2017

\begin{abstract}
ABSTRAK
Perkembangan ilmu pengetahuan tidak terlepas dari perkembangan manusia di dunia, dengan ilmu pengetahuan dan teknologi yang tercipta. Pada era informasi saat ini, informasi menjadi sangat berharga dan menjadi tolak ukur perkembangan suatu masyarakat. Teknologi informasi pada saat ini menawarkan peluang bagi peningkatan dan kemudahan efisiensi kerja. Media sosial sebagai salah satu sarana informasi dan alat komunikasi yang memfasilitasi hubungan antara satu dengan lainnya. Semakin berkembangnya teknologi informasi dan telekomunikasi saat ini berdampak baik untuk perkembangan pelayanan suatu perpustakaan. Kemudahan dalam media sosial berdampak pada pelayanan ke pemustaka pelayanan informasi yang dimanfaatkan melalui web atau jejaring sosial lainnya. Twitter, whatsapp, youtube, pinterest, Instagram dan Facebook merupakan contoh dari jejaring sosial yang bermunculan di jejaring sosial saat ini, dimana pemanfaatannya dapat digunakan dan di terapkan di perpustakaan. Dengan cara mempromosikan koleksi dan informasi yang ada di perpustakaan, sehingga penyampaian informasi yang dibutuhkan pemustaka bisa lebih tepat, cepat dan mudah.
\end{abstract}

Kata Kunci : media social; perpustakaan; promosi; informasi; pemustaka.

\section{ABSTRACT}

The development of the science is inseparable from human development in the world, with science and technology. In the current information era, information becomes very valuable and become a benchmark of a society's development. Information technology at this time offers opportunities for increased efficiency and ease of work. Social media as a communication tool that facilitates a relationship between one another. Growing information technology and telecommunications are currently impacting both for the development of the service of a library. Ease in social media impact on the services to the user information service that is utilized through the web or other social networks. Twitter, whatsapp, youtube, pinterest, instagram and facebook is a great example of social networking are popping up in the current of social networking, where it is used can be used and applied in the library. By promoting the collection and information in the library, so that the delivery of the needed information a user can more accurately, quickly and easily.

Keywords : Social media; library; promotion; information, users.

\footnotetext{
Korespondensi penulis:

Gedung BRSDM II, Jl. Pasir Putih II, Ancol Timur, Jakarta Utara

Email : arief_goen@yahoo.com
} 


\section{PENDAHULUAN}

Perpustakaan adalah institusi pengelola koleksi karya tulis, karya cetak, dan/atau karya rekam secara profesional dengan sistem yang baku guna memenuhi kebutuhan pendidikan, penelitian, pelestarian, informasi, dan rekreasi para pemustaka (UU No. 43 Tahun 2007). Sedangkan Perpustakaan Khusus merupakan institut/unit kerja pengelola karya tulis, karya tulis cetak, dan karya rekam yang dikelola secara professional berdasarkan system yang baku untuk mendukung kelancaran/keberhasilan pencapaian visi, misi dan tujuan instasi induk informasi yang menaunginya (Badan Standarisasi Nasional, 2009). Perpustakaan khusus sebagai suatu organisasi informasi pemerintahaan yang bertugas mengumpulkan, menyimpan dan menyebarkan informasi dengan menekankan suatu koleksi pada suatu bidang tertentu dan bidang-bidang yang berhubungan dengan pemustaka. Perpustakaan khusus mempunya ciri sebagai berikut (1) koleksi informasi yang ada lebih diutamakan untuk memenuhi kebutuhan organisasi induk, berada di bawah suatu organisasi induk; (2) masyarakat yang dilayani terbatas pada staf yang ada di lingkungan organisasi induk dan anggota asosiasi yang berada di organisasi tersebut; (3) ruang lingkup subjek berorientasi pada satu subjek tertentu atau beberapa subjek yang berhubungan dengan bidang kegiatan dan minat organisasi induk. Selain itu, ukuran perpustakaan khusus biasanya kecil dan dikelola oleh pustakawan yang berperan sebagai ahli informasi dan manajer (Tambunan, 2013).

Perpustakaan khusus tentunya berbeda dengan perpustakan lainnya, seperti perpustakaan sekolah dan perguruan tinggi. Perbedaan yang sangat menonjol terlihat dari tugas pokok perpustakaan tersebut dan kebutuhan informasi yang disampaikan ke pemustaka. Dengan demikian pustakawan harus dapat menganalisis setiap kebutuhan informasi pemustaka.

Keberadaan fungsi dan layanan perpustkaan khusus lebih diminati oleh penguna perpustkaan, sehingga memacu para pemustaka untuk lebih berinovasi dalam mempromosikan layanan dengan cara komunikatif interaktif. Baik melalui media sosial Twitter, whatsup, youtube, pinterest, Instagram dan Facebook maupun secara langsung kepada penguna perpustakaan.

\section{TINJAUAN PUSTAKA}

Media sosial adalah sebuah media online, dengan para pemustakanya bisa dengan mudah berpartisipasi, berbagi, dan menciptakan isi meliputi blog, jejaring sosial, wiki, forum dan dunia virtual. Blog, jejaring sosial dan wiki merupakan bentuk media sosial yang paling umum digunakan oleh masyarakat di seluruh dunia.

Andreas Kaplan \& Michael Haenlein (2010) mendefinisikan media sosial sebagai "sebuah kelompok aplikasi berbasis internet yang membangun di atas dasar ideologi dan teknologi Web 2.0, dan yang memungkinkan penciptaan dan pertukaran user-generated content'.

Media sosial mempunyai ciri - ciri sebagai berikut (Gambel, M. \& T.K. Gambel, 2002) :

- Pesan yang di sampaikan tidak hanya untuk satu orang saja namun bisa keberbagai banyak orang contohnya pesan melalui SMS ataupun internet

- Pesan yang di sampaikan bebas, tanpa harus melalui suatu Gatekeeper

- Pesan yang di sampaikan cenderung lebih cepat di banding media lainnya

- Penerima pesan yang menentukan waktu interaksi

\section{METODE}

Metode yang digunakan adalah melalui studi pustaka melalui buku-buku, artikel jurnal online maupun artikel media cetak yang berkaitan dengan media sosial dan penggunaannya untuk perpustakaan.

\section{HASIL DAN PEMBAHASAN}

Perkembangan teknologi informasi pada sekarang ini sangat mempermudah di dalam pekerjaan. Perpustakaan sebagai lembaga penyedia informasi memiliki peranan penting dalam penyediaan informasi untuk pemustaka, sahinga dapat memperoleh informasi secara cepat, efektif dan efisien. Berkembangnya teknologi informasi saat ini dapat membawa perubahan dala pelayanan dalam perpustakaan, hal ini dapat dimanfaatkan melalui jejaring sosial maupun media sosial yang berbasis web seperti Twitter, whatsup, youtube, pinterest, Instagram dan Facebook yang semakin viral dikalangan penguna media sosial. Sehingga dapat diterapkan di perpustakaan. 
Media sosial teknologi mengambil berbagai bentuk termasuk majalah, forum internet, weblog, blog sosial, microblogging, wiki, podcast, foto atau gambar, video, peringkat dan bookmark sosial. Dengan menerapkan satu set teori-teori dalam bidang media penelitian (kehadiran sosial, media kekayaan) dan proses sosial (self-presentasi, selfdisclosure) (Kaplan \& Haenlein, 2010) menciptakan skema klasifikasi untuk berbagai jenis media sosial dalam artikel Horizons Bisnis mereka diterbitkan dalam 2010 , ada enam jenis media social :

1. Proyek kolaborasi : Website mengizinkan usernya untuk dapat mengubah, menambah, ataupun meremove konten - konten yang ada di website ini. contohnya wikipedia

2. Blog dan microblog : User lebih bebas dalam mengekspresikan sesuatu di blog ini seperti curhat ataupun mengkritik kebijakan pemerintah. contohnya twitter

3. Konten : para user dari pemustaka website ini saling meng-share konten - konten media, baik seperti video, ebook, gambar, dan lain lain. contohnya youtube

4. Situs jejaring social : Aplikasi yang mengizinkan user untuk dapat terhubung dengan cara membuat informasi pribadi sehingga dapat terhubung dengan orang lain. Informasi pribadi itu bisa seperti foto - foto. contoh facebook

5. Virtual game world : Dunia virtual, di mana mengreplikasikan lingkungan 3D, di mana user bisa muncul dalam bentuk avatar avatar yang diinginkan serta berinteraksi dengan orang lain selayaknya di dunia nyata. contohnya game online.

6. Virtual social world : Dunia virtual yang di mana pemustakanya merasa hidup di dunia virtual, sama seperti virtual game world, berinteraksi dengan yang lain. Namun, Virtual Social World lebih bebas, dan lebih ke arah kehidupan, contohnya second life.

Menurut Antony Mayfield (2008) media sosial adalah mengenai menjadi manusia biasa. Manusia biasa yang saling membagi ide, bekerjasama, dan berkolaborasi untuk menciptakan kreasi, berpikir, berdebat, menemukan orang yang bisa menjadi teman baik, menemukan pasangan, dan membangun sebuah komunitas. Intinya, menggunakan media sosial menjadikan kita sebagai diri sendiri. Selain kecepatan informasi yang bisa diakses dalam hitungan detik, menjadi diri sendiri dalam media sosial adalah alasan mengapa media sosial berkembang pesat. Tak terkecuali, keinginan untuk aktualisasi diri dan kebutuhan menciptakan personal branding.

Teknologi dapat memberikan dampak baik maupun buruk, semua itu berngantung kembali kepada pihak penguna media social tersebut. Demikian dengan perkembangan media social dapat dimanfaatkan melalui jejaring social dan web, sehingga memberikan kemudahan penguna perpustkaan dlam mengakses data yang diperlukan.

- Sebagai tempat untuk berdiskusi dan berinteraksi tanpa harus saling bertemu secara fisik, dapat dilakukan melalui forum diskusi dan media social.

- Tempat mencari buku tanpa mengunakan penelusuran cukup dengan jejaring social.

- Meminjam buku cukup dengan scan barcode tanpa harus datang ke pustakawan.

- Sebagai media penunjang untuk penyampaian informasi kepada pemustaka melalui jejaring social, sehingga penguna dapat mendownload file yang telah di upload oleh pustakawan melalui jejaring social.

- Sebagai media promosi dalam kemajuan perpustakaan.

Tujan dari media sosial yang paling digunakan oleh penguna adalah Twitter, Facebook dan Instagram pada saat ini. Perpustakaan setidaknya memliki salah satu dari akun tersebut, tujuannya untuk membangun interaksi antara pustakawan dan pemustaka dalam menginformasikan berbagai aktifitas yang berkaitan dengan perpustakaan.

Kehadiran jejaring sosial di era teknologi juga mempunyai efek positif dan negatif sebagai penguna, penerapan media sosisal untuk membantu penguna terutama perpustakaan UPT di daerah dalam penyampaian informasi mengenai koleksi perpustakaan dan hal yang terkait lainnya. Walaupun media sosial dibuat sebagai media promosi untuk saling berinteraksi antar penguna, tidak dapat dipungkiri bahawa media sosial memiliki dampak besar bagi kemajuan perpustakaan.

\section{KESIMPULAN}

Penerapan media sosial sebagai media promosi untuk perpustakaan agar para pemustaka tidak perlu susah payah untuk mencari informasi 
yang diperlukan dan melakukan information sharing melalui media sosial. Sesuai dengan indentifikasi kebutuhan informasi pemustaka, menetapkan inovatif promosi, sumber pendukung, penetapan media promosi. Sehingga perpustkaan dapat mengoptimalkan media sosial sebagai media efektif untuk memberikan pelayanan bagi pemustaka.

\section{DAFTAR PUSTAKA}

Antony Mayfield. (2008). (Ebook) What is Social Media?. iCrossing. London

Badan Standarisasi Nasional. (2009). SNI 7496:2009 Perpustakaan khusus instansi permerintah. Jakarta

Gamble, M., \& Gamble, T. K. (2002). Communication Work, $7^{\text {th }}$ Edition. Boston, McGraw-Hill College.
Http: windakusuma.note.fisip.uns.ac.id.

Kaplan, A. M. \& Haenlein, M. (2010). "Users of the world, unite! The challenges and opportunities of Social Media". Business Horizons 53(1): 59-68.

Perpustakaan Nasional Republik Indonesia. (2007). Undang-udang No. 43 Tahun 2007 tentang Perpustakaan. Perpustakaan Nasional Republik Indonesia. Jakarta

Tambunan, K. (2013). Kajian Perpustakaan Khusus dan Sumber Informasi di Indonesia. BACA: Jurnal Dokumentasi dan Informasi, 34 (1). 